\title{
A Validated Stability-Indicating Liquid Chromatographic Method for the Determination of Exemestane
}

\author{
M. MATHRUSRI ANNAPURNA*, B. SWATI, D. NAGA RAMYA, \\ K. PRAMADVARA, A. SRI RAM and N. ASLESHA
}

Department of Pharmaceutical Analysis \& Quality Assurance, GITAM Institute of Pharmacy, GITAM University, Visakhapatnam, India mathrusri2000@yahoo.com

Received 20 February 2014 / Accepted 26 March 2014

\begin{abstract}
A stability indicating liquid chromatographic method was developed for the determination of Exemestane in presence of degradation products using Zorbax SB C18 $(150 \mathrm{~mm} \times 4.6 \mathrm{~mm} i$. d., $3.5 \mu \mathrm{m}$ particle size) column with a flow rate $1.2 \mathrm{~mL} / \mathrm{min}$ (UV detection $247 \mathrm{~nm}$ ). Linearity was observed over a concentration range $0.1-200 \mu \mathrm{g} / \mathrm{mL}$ with regression equation $\mathrm{y}=56288 \mathrm{x}-3004\left(\mathrm{R}^{2}\right.$ $=0.999)$. Forced degradation studies were performed and Exemestane is reported to be highly sensitive towards oxidation. The method was validated as per ICH guidelines.
\end{abstract}

Keywords: Exemestane, Liquid chromatography, Validation, Stability-indicating, ICH

\section{Introduction}

Exemestane (6-methylen-androsta-1, 4-diene-3, 17-dione) is a lipophilic steroid drug. It is an orally active irreversible steroidal aromatase inhibitor used for the therapy of metastatic postmenopausal breast cancer, with estrogen-dependent pathological conditions ${ }^{1-3}$. It was shown to be a potent and selective-inhibitor of aromatase vitro and in vivo. The introduction of a 1,2-double bond in the ring of steroid molecule increase the aromatase inactivator affinity for the aromatase enzyme, which leads to increased therapeutic potency ${ }^{4}$.

Literature survey reports that Exemestane can be determined by different analytical techniques such as HPTLC ${ }^{5}$, UV-spectrophotometry ${ }^{6}$, GC-MS $^{7}$, LC-MS $^{8-12}$, LC-radio immuno assay ${ }^{13}, \mathrm{HPLC}^{14-17}$ and $\mathrm{UPLC}^{18}$ in pharmaceutical dosage forms and in biological fluids. So far only two stability indicating HPLC ${ }^{19-20}$ methods were reported for the determination of Exemestane and at present the authors have proposed a robust, precise and accurate stability indicating liquid chromatographic method for the determination of Exemestane in pharmaceutical dosage forms.

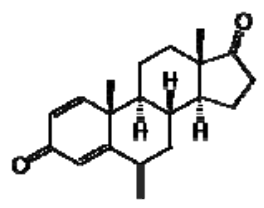

Figure 1. Chemical structure of Exemestane 


\section{Experimental}

Exemestane standard (purity 99\%) was obtained from Natco Pharma Ltd. (India) and was used as it is without further purification. All other chemicals were of analytical grade (Merck).

Exemestane is available as film coated tablets and tablets (Label claim $25 \mathrm{mg}$ ) with brand names $\mathrm{X}^{\prime} \mathrm{CEL}^{\circledR}$ (Celon Laboratories Ltd., India) and $\mathrm{XTANE}^{\circledR}$ (Natco Pharma Ltd, India) respectively.

\section{Preparation of phosphate buffer ( $p H 4.0$ ) solution}

$5.04 \mathrm{~g}$ of Di sodium hydrogen phosphate and $3.01 \mathrm{~g}$ of potassium dihydrogen phosphate was accurately weighed and dissolved in HPLC grade water in a $1000 \mathrm{~mL}$ volumetric flask. $\mathrm{pH}$ was adjusted to 4.0 using glacial acetic acid.

\section{Instrumentation and chromatographic conditions}

Chromatographic separation was achieved by using Zorbax SB-C18 column (150 mm $\times$ $4.6 \mathrm{~mm}$ i.d., $3.5 \mu \mathrm{m}$ particle size) for HPLC system of Shimadzu Model CBM-20A/20 Alite, equipped with SPD M20A prominence photodiode array detector, maintained at $25^{\circ} \mathrm{C}$.

Isocratic elution was performed using phosphate buffer: acetonitrile $(40: 60, \mathrm{v} / \mathrm{v})$ as mobile phase. The overall run time was $10 \mathrm{~min}$. with flow rate $1.2 \mathrm{~mL} / \mathrm{min}$ with UV detection at $247 \mathrm{~nm} .20 \mu \mathrm{L}$ of sample was injected into the HPLC system.

\section{Preparation of stock solution}

Stock solution was prepared by accurately transferring about $10 \mathrm{mg}$ of Exemestane in to a $10 \mathrm{~mL}$ volumetric flask with mobile phase.

Further dilutions were made from the stock solution with mobile phase (phosphate buffer: acetonitrile $(40: 60, \mathrm{v} / \mathrm{v})$. Prior to injection all solutions were filtered through $0.45 \mu \mathrm{m}$ membrane filter.

\section{Method validation}

The method was validated for linearity, limit of quantitation (LOQ), limit of detection (LOD), intra/inter-day precision, accuracy, robustness and specificity ${ }^{21}$.

\section{Linearity}

Linearity test solutions for the assay method were prepared from a stock solution at different concentration levels of the assay analyte concentration $(0.1-200 \mu \mathrm{g} / \mathrm{mL}) .20 \mu \mathrm{L}$ of each solution was injected in to the HPLC system and the peak area of the chromatogram obtained was noted. A graph was drawn by taking the concentration of the drug on the $x$-axis and the corresponding peak area on the $y$-axis.

\section{Limit of quantification (LOQ) and limit of detection (LOD)}

The limit of quantification (LOQ) and limit of detection (LOD) were based on the standard deviation of the response and the slope of the constructed calibration curve as described in International Conference on Harmonization guidelines Q2 (R1) ${ }^{21}$.

\section{Precision}

The intra-day precision of the assay method was evaluated by carrying out 9 independent assays of a test sample of Exemestane at three concentration levels $(10,20$ and $50 \mu \mathrm{g} / \mathrm{mL})$ against a qualified reference standard. The $\%$ RSD of three obtained assay values at three different concentration levels was calculated. 
The inter-day precision study was performed on three different days i.e. day 1, day 2 and day 3 at three different concentration levels $(10,20$ and $50 \mu \mathrm{g} / \mathrm{mL})$ and each value is the average of three determinations. The \% RSD of three obtained assay values on three different days was calculated.

\section{Accuracy}

The accuracy of the assay method was evaluated in triplicate at three concentration levels $(80$, 100 and $120 \%$ ) and the percentage recoveries were calculated. Standard addition and recovery experiments were conducted to determine the accuracy of the method for the quantification of Exemestane in the drug product. The study was carried out in triplicate at a total concentration 18,20 and $22 \mu \mathrm{g} / \mathrm{mL}$. The percentage recovery in each case was calculated.

\section{Robustness}

The robustness of the assay method was established by introducing small changes in the HPLC conditions which included wavelength (245 and $249 \mathrm{~nm})$, percentage of acetonitrile in the mobile phase (58 and $62 \%)$, flow rate $(1.1$ and $1.3 \mathrm{~mL} / \mathrm{min})$ and $\mathrm{pH}(3.9$ and 4.1$)$. Robustness of the method was studied with $50 \mu \mathrm{g} / \mathrm{mL}$ of Exemestane.

\section{Analysis of commercial formulations (Tablets)}

Twenty tablets were procured from the local pharmacy store, weighed and crushed in to fine powder. Powder equivalent to about $10 \mathrm{mg}$ Exemestane was accurately transferred into a $10 \mathrm{~mL}$ volumetric flask and made up to volume with acetonitrile. The contents were sonicated for $30 \mathrm{~min}$ to enable complete dissolution of Exemestane and then the solution was filtered. The filtrate was further diluted with mobile phase to yield $50 \mu \mathrm{g} / \mathrm{mL}$.

\section{Forced degradation studies/Specificity}

Forced degradation studies were performed to evaluate the stability indicating properties and specificity of the method ${ }^{22}$. All solutions for use in stress studies were prepared at an initial concentration of $1 \mathrm{mg} / \mathrm{mL}$ of Exemestane and refluxed for $30 \mathrm{~min}$ at $80^{\circ} \mathrm{C}$ in thermostat and then diluted with mobile phase to give a final concentration of $50 \mu \mathrm{g} / \mathrm{mL}$ All the solutions were analysed after 24 hours.

The acidic and alkaline degradations were performed using hydrochloric acid $(0.1 \mathrm{M})$ and in sodium hydroxide $(0.1 \mathrm{M})$ at $80^{\circ} \mathrm{C}$ in a thermostat and the stressed samples were instantly cooled with a mixture of ice and water, neutralized and diluted with mobile phase as per the requirement. Oxidation was performed using $\mathrm{H}_{2} \mathrm{O}_{2}$ solution where as thermal degradation was performed at $80{ }^{\circ} \mathrm{C}$ in a thermostat for 6 hours.

\section{Results and Discussion}

The authors have developed a validated stability indicating RP-HPLC method for Exemestane in presence of degradation products. The performance characteristics of the present stability indicating liquid chromatographic method was compared and discussed with the previously published methods in Table 1 .

\section{HPLC method development and optimization}

Initially the drug samples were analyzed using a mobile phase consisting of phosphate buffer solution: acetonitrile $(50: 50, \mathrm{v} / \mathrm{v})$ with a flow rate of $1.0 \mathrm{~mL} / \mathrm{min}$ where a sharp peak was eluted at $8.49 \mathrm{~min}$. Therefore the flow rate was modified to $1.2 \mathrm{~mL} / \mathrm{min}$ for which the retention time of the drug was less than $2 \mathrm{~min}$ (UV detection at $247 \mathrm{~nm}$ ) and therefore the 
mobile phase was slightly changed as $(40: 60, \mathrm{v} / \mathrm{v})$ with the same flow rate and selected as the suitable chromatographic conditions for the entire study.

Table 1. Comparison of the performance characteristics of Exemestane of the present method with the published HPLC methods

\begin{tabular}{|c|c|c|c|}
\hline Method/Reagent & $\begin{array}{l}\text { Linearity } \\
\mu \mathrm{g} / \mathrm{mL}\end{array}$ & Remarks & Ref. \\
\hline $\begin{array}{c}\text { Chloroform: methanol } \\
(9.2: 0.8)(\mathrm{v} / \mathrm{v})\end{array}$ & $100-500$ & HPTLC & {$[5]$} \\
\hline $\begin{array}{c}\text { Ammonium acetate: acetonitrile } \\
(\mathrm{pH} \mathrm{3.5)}\end{array}$ & $10-100$ & $\begin{array}{c}\text { LC/MS } \\
\text { (Human urine) }\end{array}$ & {$[8]$} \\
\hline Acetonitrile $(100 \%)$ & $0.05-25$ & $\begin{array}{c}\text { LC/MS/MS } \\
\text { (Human plasma) }\end{array}$ & [9] \\
\hline $\begin{array}{c}\text { Ammonium acetate: acetonitrile } \\
(\mathrm{pH} 4.5)(60: 40, \mathrm{v} / \mathrm{v})\end{array}$ & 1 to 50 & LC/MS & {$[10]$} \\
\hline Formic acid: acetonitrile & $0.1-40$ & $\begin{array}{c}\text { LC/MS- } \\
\text { (Human plasma) }\end{array}$ & {$[11]$} \\
\hline Formic acid: acetonitrile & - & $\begin{array}{c}\text { LC/MS } \\
\text { (Human Urine) }\end{array}$ & {$[12]$} \\
\hline Acetonitrile-water (34:66) & $\begin{array}{c}10-500 \\
20-1000\end{array}$ & $\begin{array}{l}\text { LC and Radio } \\
\text { Immunoassay } \\
\text { (Human plasma) }\end{array}$ & {$[13]$} \\
\hline $\begin{array}{l}\text { Acetonitrile: } \mathrm{KH}_{2} \mathrm{PO}_{4} \\
(\mathrm{pH} 4.5)(35: 65, \mathrm{v} / \mathrm{v})\end{array}$ & $10-1000$ & $\begin{array}{c}\text { Not Stability indicating } \\
\text { HPLC }\end{array}$ & {$[14]$} \\
\hline $\begin{array}{l}\text { Acetonitrile: water } \\
(44: 56, \mathrm{v} / \mathrm{v})\end{array}$ & $2.5-50$ & Low linearity range & {$[15]$} \\
\hline Methanol: phosphate buffer & $20-100$ & $\begin{array}{l}\text { Low linearity range } \\
\text { (Gradient mode) }\end{array}$ & {$[16]$} \\
\hline $\begin{array}{l}\text { Water and methanol } \\
(50: 50, \mathrm{v} / \mathrm{v})\end{array}$ & $25-150$ & Low linearity range & {$[17]$} \\
\hline Acetonitrile-water & - & UPLC & {$[18]$} \\
\hline Water: methanol & $25-150$ & Low linearity range & [19] \\
\hline Acetonitrile-water $(60: 40, \mathrm{v} / \mathrm{v})$ & 6 to 14 & Low linearity range & {$[20]$} \\
\hline $\begin{array}{l}\text { Phosphate buffer: acetonitrile } \\
(\mathrm{pH} 4.0)(40: 60, \mathrm{v} / \mathrm{v})\end{array}$ & $0.1-200$ & $\begin{array}{c}\text { Stability indicating } \\
\text { HPLC }\end{array}$ & $\begin{array}{l}\text { Present } \\
\text { work }\end{array}$ \\
\hline
\end{tabular}

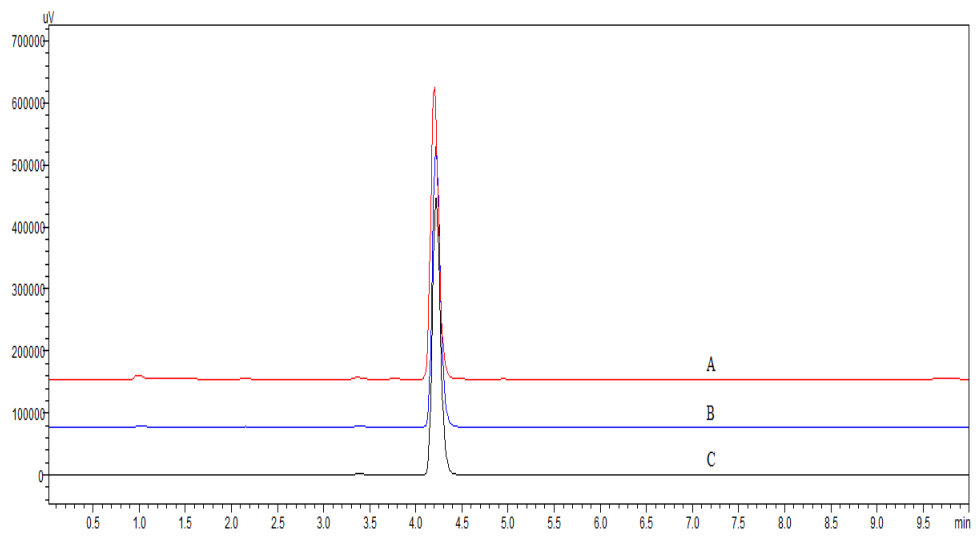

Figure 2. Typical Chromatograms of Exemestane $(50 \mu \mathrm{g} / \mathrm{mL})(\mathrm{A}), \mathrm{X}^{\prime} \mathrm{CEL}^{\circledR}$ (B) XTANE ${ }^{\circledR}$ (C) (Label claim: $25 \mathrm{mg}$ ) 
The typical chromatogram obtained for Exemestane was shown in Figure 2A. Exemestane obeys Beer-Lambert's law over the concentration range 0.1-200 $\mu \mathrm{g} / \mathrm{mL}$ (Table 2) with regression equation $y=56288 x+3004\left(r^{2}=0.999\right)$ (Figure 3$)$.

Table 2. Linearity of Exemestane

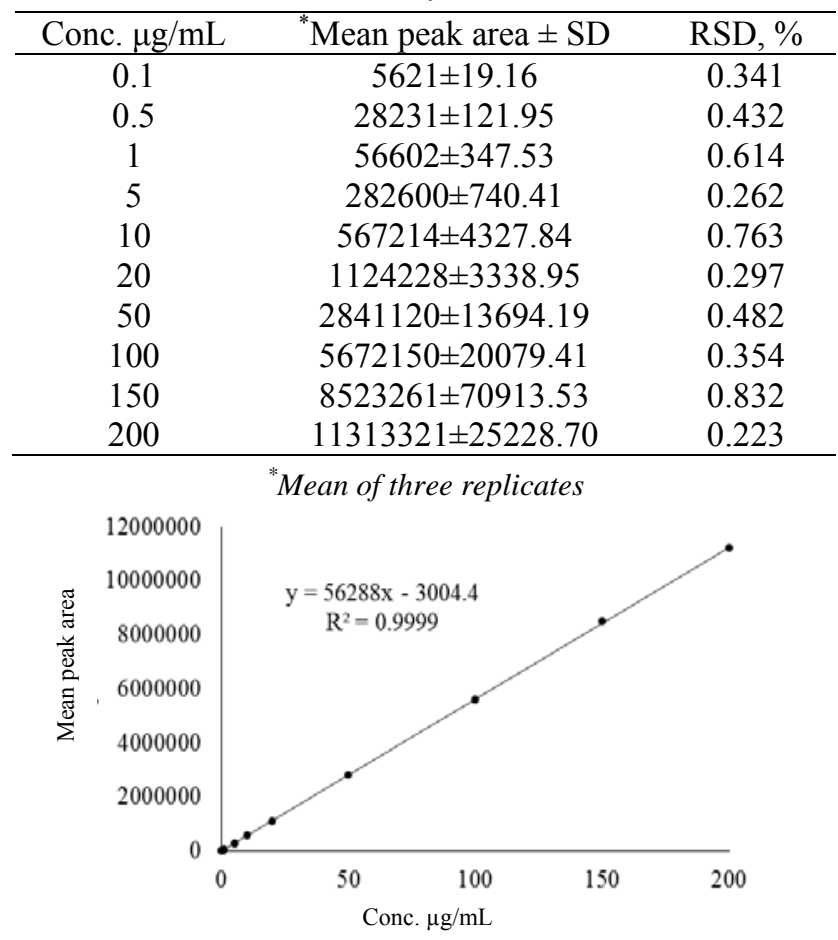

Figure 3. Calibration curve of Exemestane

The LOQ and LOD were determined based on the 10 and 3.3 times the standard deviation of the response, respectively, divided by the slope of the calibration curve. The LOQ is found to be $0.0823 \mu \mathrm{g} / \mathrm{mL}$ and the LOD is found to be $0.0272 \mu \mathrm{g} / \mathrm{mL}$.

Table 3. Precision and accuracy studies of Exemestane

\begin{tabular}{|c|c|c|c|}
\hline \multirow{2}{*}{$\begin{array}{l}\text { Conc. } \\
\mu \mathrm{g} / \mathrm{mL}\end{array}$} & Intra-day precision & \multicolumn{2}{|c|}{ Inter-day precision } \\
\hline & ${ }^{*}$ Mean peak area $\pm \mathrm{SD}(\% \mathrm{RSD})$ & \multicolumn{2}{|c|}{$\begin{array}{c}\text { Mean peak area } \pm \text { SD } \\
(\% \mathrm{RSD})\end{array}$} \\
\hline 10 & $561256 \pm 2245.02(0.4)$ & \multicolumn{2}{|c|}{$560089 \pm 3752.59(0.67)$} \\
\hline 20 & $1115512 \pm 3569.63(0.32)$ & \multicolumn{2}{|c|}{$1106782 \pm 5976.62(0.54)$} \\
\hline 50 & $2814289 \pm 15197.16(0.54)$ & \multicolumn{2}{|c|}{$2803299 \pm 23267.38(0.83)$} \\
\hline \multicolumn{4}{|c|}{ Accuracy } \\
\hline $\begin{array}{l}\text { Conc. } \\
\mu \mathrm{g} / \mathrm{mL}\end{array}$ & $\begin{array}{c}\text { Mean peak area } \pm \text { SD } \\
(\% \text { RSD })\end{array}$ & $\begin{array}{l}\text { Drug found } \\
\mu \mathrm{g} / \mathrm{mL}\end{array}$ & $\begin{array}{c}\text { Recovery } \\
\%\end{array}$ \\
\hline 18 & $992898.4 \pm 4567.33(0.46)$ & 17.49 & 97.16 \\
\hline 20 & $1104332 \pm 3644.29(0.33)$ & 19.76 & 98.80 \\
\hline 22 & $1204776.2 \pm 7710.56(0.64)$ & 21.53 & 97.86 \\
\hline
\end{tabular}


The \% RSD was found to be 0.32-0.54 (intra-day) and 0.54-0.83 (inter-day) in precision studies where as in accuracy studies the percentage RSD was found to be $0.33-0.64$ with a percentage recovery of $97.16-98.80 \%$ indicating that the method is precise and accurate (Table 3). The percentage RSD in robustness study was found to be $0.15-1.17$ which is less than $2.0 \%$ indicating that the proposed method is robust (Table 4).

Table 4. Robustness study of Exemestane

\begin{tabular}{cccc}
\hline Parameter & Condition & $\begin{array}{c}{ }^{*} \text { Mean } \\
\text { peak area }\end{array}$ & $\begin{array}{c}{ }^{*} \text { Mean peak area } \pm \text { SD } \\
(\% \text { RSD })\end{array}$ \\
\hline Flow rate & 1.1 & 2819545 & $2835697.67 \pm 14238.16$ \\
$( \pm 0.1 \mathrm{~mL} / \mathrm{min})$ & 1.2 & 2841120 & $(0.50)$ \\
Detection wavelength & 1.3 & 2846428 & \\
$( \pm 2 \mathrm{~nm})$ & 245 & 2814014 & $2834343.67 \pm 17929.12$ \\
& 247 & 2841120 & $(0.63)$ \\
Mobile phase composition & $38: 62$ & 2843125 & \\
phosphate buffer: acetonitrile & $40: 60$ & 2841120 & $2840480.33 \pm 3015.82$ \\
$( \pm 2 \%, \mathrm{v} / \mathrm{v})$ & $42: 58$ & 2837196 & $(0.11)$ \\
& 3.9 & 2812945 & \\
$\mathrm{pH}( \pm 0.1 \mathrm{unit})$ & 4.0 & 2841120 & $2837951.33 \pm 23582.21$ \\
& 4.1 & 2859789 & $(0.83)$ \\
\hline
\end{tabular}

*Mean of three replicates

\section{Analysis of commercial formulations (Tablets)}

The proposed method was applied to the determination of Exemestane tablets and the assay was calculated as $95.89-96.65 \%$ (Table 5) and no interference was observed with the excipients (Figure 2B-2C).

Table 5. Analysis of Exemestane commercial formulation (Tablets)

\begin{tabular}{cccc}
\hline Formulation & Labeled claim, mg & *Amount found, mg & *Recovery \% \\
\hline XTANE & 25 & 24.16 & 96.65 \\
X'CEL & 25 & 23.97 & 95.89 \\
\hline \multicolumn{3}{c}{ *Mean of three replicates }
\end{tabular}

\section{Forced degradation studies/Specificity}

The representative chromatograms obtained during the forced degradation studies of Exemestane were shown in Figure 4B-4E. Exemestane was eluted at $4.195 \mathrm{~min}$ and the overall runtime was $10 \mathrm{~min}$ (Figure 4A). 58.26\% Exemestane was more destroyed in oxidative environment (Figure 4D) with a degradant peak at 1.149 min. 3.89\% Exemestane has undergone alkaline degradation. Exemestane has undergone 3.51, 5.20 and $4.97 \%$ degradation during acidic, thermal and photolytic degradations respectively which is less than 10\% (Table 6). In all the studies Exemestane has reported theoretical plates more than 2000 and the tailing factor less than 1.5 indicating that the proposed method is selective. When exposed to stress conditions Exemestane retains its symmetry and did not interfere with the degradant peaks indicating that the method is specific. 
Table 6. Forced degradation studies of Exemestane

\begin{tabular}{cccccc}
\hline Stress conditions & $\begin{array}{c}{ }^{*} \text { Mean } \\
\text { peak area }\end{array}$ & $\begin{array}{c}{ }^{*} \text { Drug } \\
\text { recovered } \\
\%\end{array}$ & $\begin{array}{c}{ }^{*} \text { Drug } \\
\text { decomposed } \\
\%\end{array}$ & $\begin{array}{c}\text { Theoretical } \\
\text { plates }\end{array}$ & $\begin{array}{c}\text { Tailing } \\
\text { factor }\end{array}$ \\
\hline $\begin{array}{c}\text { Standard Drug } \\
\text { Acidic degradation }\end{array}$ & 2841120 & 100 & - & 9206.195 & 1.297 \\
Alkaline degradation & 2730488 & 94.66 & 5.34 & 9250.263 & 1.311 \\
Oxidative degradation & 1185987 & 41.74 & 3.89 & 9134.839 & 1.308 \\
Thermal degradation & 2526241 & 88.92 & 11.08 & 8978.593 & 1.440 \\
\hline
\end{tabular}

*Mean of three replicates

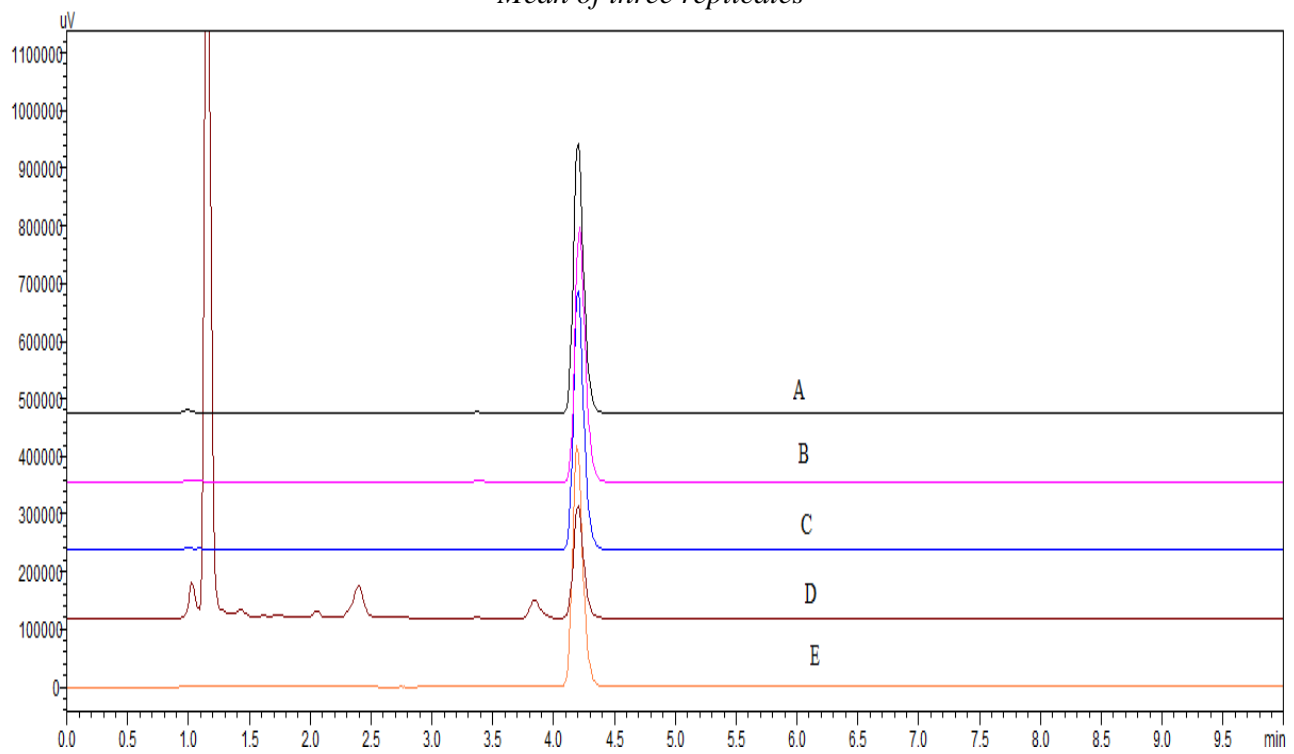

Figure 4. Typical Chromatograms of Exemestane $[\mathrm{A}]$, acidic $[\mathrm{B}]$, alkaline $[\mathrm{C}]$, and oxidative [D], thermal [E] degradations

\section{Conclusion}

This stability-indicating and validated HPLC method is selective, precise and accurate and can be applied for the determination of Exemestane.

\section{Acknowledgment}

The authors are grateful to M/s GITAM University for providing necessary research facilities and NATCO Pharma Ltd. India or providing the gift samples of Exemestane.

\section{References}

1. Johannessen D C, Engan T, Di Salle E, Zurlo M G, Paolini J, Ornati G, Piscitelli G, Kvinnsland S and Lonning P E, Clin Cancer Res., 1997, 3, 1101-1108.

2. Evans T R, Di Salle E, Ornati G, Lassus M, Benedetti M S, Painezzola E and Coombes R C, Cancer Res., 1992, 52, 5933-5939.

3. Geisler J, King N, Anker G, Ornati G, Di Salle E, Lonning P E and Dowsett M, Clin Cancer Res, 1998, 4, 2089-2093. 
4. Kenneth R Korzekwa, William F Trager, Soozy J Smith, Yoichi Osawa and James R Gillette, Biochemistry, 1991, 30(25), 6155-6162; DOI:10.1021/bi00239a011

5. Maya B Mane, Jaiprakash N Sangshetti, Parmeshwar J Wavhal, Pravin S Wakte and

Devanand B Shinde, Arabian J Chem., 2010, 2, 1016;

DOI:10.1016/j.arabjc.2010.11.009

6. Angalaparameswari S, Thiruvengadarajan V S, Amruth Kumar N, Kutumbarao M, Ramkanth S and Adhusudhanachetty C, J Chem., 2012, 9(4), 2068-2073; DOI:10.1155/2012/782738

7. Gustavo de Albuquerque Cavalcanti, Bruno Carius Garrido, Felipe Dias Leal, Monica Costa Padilha, Xavier de la Torre and Francisco Radler de Aquino Neto, Steroids, $2011,76,1010$.

8. Ute Mareck, Hans Geyer, Sven Guddat, Nadine Haenelt, Maxie Kohler, Georg Opfermann, Mario Thevis, Anja Koch and Wilhelm Schanzer, Rapid Commun Mass Spectrom., 2006, 20(12), 1954-1962; DOI:10.1002/rcm.2545

9. Cenacchi V, Baratte S, Cicioni P, Frigerio E, Long J and James C, J Pharm Biomed Anal, 2000, 22(3), 451-460; DOI:10.1016/S0731-7085(00)00235-1

10. Allievi C, Zugnoni P, Strolin Benedetti M and Dostert P J, Mass Spectrom., 1995, 30(5), 693-697; DOI:10.1002/jms.1190300506

11. Hanna Ksycinska, Katarzyna Bus Kwasnik, Anna Szlagowska and Piotr J Rudzki, $J$ Chromatogr B, 2011, 879(21), 1905-1910; DOI:10.1016/j.jchromb.2011.05.015

12. Gustavode Albuquerque Cavalcanti, Bruno Carius Garrido, Felipe Dias Leal, Monica Costa Padilha, Monica Mazzarino, Xavier de la Torre, Francesco Botre and Francisco Radler de Aquino Neto, J Steroid Biochem Molecular Biol., 2011, 127(3-5), 248-254; DOI:10.1016/j.jsbmb.2011.08.014

13. Persiani S, Broutin F, Cicioni P, Stefanini P and Strolin Benedetti M, Eur J Pharm Sci., 1996, 4(6), 331-340; DOI:10.1016/S0928-0987(96)00171-6

14. Breda M, Piannezzola E and Strolin Benedetti M, J Chromatogr., 1993, 620(2), 225-231.

15. Burcin Yavuz, Erem Bilensoy and Murat Sumnu. FABDA J Pharm Sci., 2007, 32(1), 15-22.

16. Uday Kumar K, Vinatha B, Sunitha P and Sushma G S, J Scientific Res Pharm., 2012, 1(3), 115-117.

17. Vijaya Lakshmi M, Seshagiri Rao J V L N and Lakshmana Rao A, Asian J Chem., 2010, 22(9), 6911-6914.

18. Maheshwar Reddy M, Hussain Reddy K, Ramkumar D, Useni Reddy M and Varaprasad B, J Pharm Res., 2011, 4(2), 546.

19. Suresh Kumar R, Narasimha Naidu, Kasa Srinivasulu, Raja Sekhar K, Veerender M and Srinivasu M K, J Pharm Biomed Anal., 2008, 50(5), 746-752; DOI:10.1016/j.jpba.2009.06.014

20. Bharath K, Ravi N Tiwari and Harshal Fegade, J Chromatogr Sci., 2011, 49(8), 634-639; DOI:10.1093/chrsci/49.8.634

21. ICH Validation of analytical procedures: Text and methodology Q2 (R1), International Conference on Harmonization, 2005.

22. ICH Stability Testing of New Drug Substances and Products Q1A (R2), International Conference on Harmonization, 2003. 